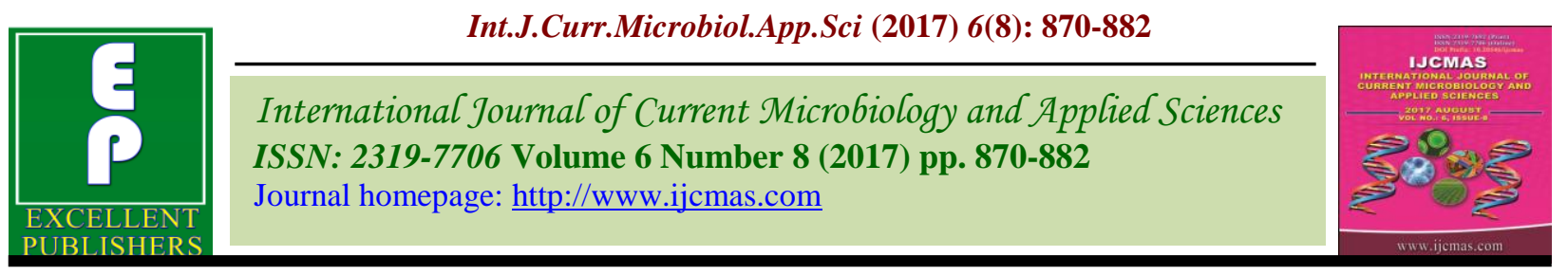

Original Research Article

https://doi.org/10.20546/ijcmas.2017.608.110

\title{
Studies on Different Methods of Drying in Carnation
}

\author{
S. Sindhuja ${ }^{1 *}$, T. Padmalatha ${ }^{1}$, A.S. Padmavathamma ${ }^{1}$ and A.L.N. $\operatorname{Prasad}^{2}$ \\ ${ }^{1}$ SKL Telangana State Horticultural University, College of Horticulture, Rajendranagar, \\ Hyderabad-30, Telangana, India \\ ${ }^{2}$ Floriculture Research Station, ARI, Rajendranagar, Hyderabad-30, Telangana, India \\ *Corresponding author
}

\begin{tabular}{|c|c|}
\hline & B S T RA C T \\
\hline & \multirow{6}{*}{$\begin{array}{l}\text { An experiment was carried out to study the influence of different methods of drying on dry } \\
\text { flower quality of carnation during the year } 2014 \text { at College of Horticulture, Rajendranagar, } \\
\text { Hyderabad. Flowers of two carnation cultivars viz., Harvey and Gaudina with } 6 \mathrm{~cm} \text { stalk } \\
\text { length were embedded in borax }+ \text { silica gel }(1: 1, \mathrm{v} / \mathrm{v}) \text { mixture and dried in shade (air } \\
\text { drying), sun, hot air oven }\left(40 \pm 1{ }^{\circ} \mathrm{C}, 45 \pm 1^{\circ} \mathrm{C}, 50 \pm 1^{\circ} \mathrm{C} \text { and } 55 \pm 1^{\circ} \mathrm{C}\right) \text { and microwave } \\
\text { oven. In total, there were fourteen treatment combinations and replicated thrice. Data were } \\
\text { statistically analyzed in Completely Randomized Design with factorial concept. The } \\
\text { results indicated that among the cultivars, 'Gaudina' recorded maximum dry flower weight } \\
(1.51 \mathrm{~g}) \text { and dry flower diameter }(3.47 \mathrm{~cm}) \text {. Maximum per cent moisture loss }(76.70) \text {, } \\
\text { minimum time for drying }(60.29 \mathrm{~h}) \text { and maximum score for color }(1.85) \text {, shape }(2.71) \text {, } \\
\text { texture }(2.06) \text { and overall acceptability }(2.26) \text { was recorded with cv. Harvey. Maximum } \\
\text { dry weight }(2.19 \mathrm{~g}) \text { and dry flower diameter }(4.07 \mathrm{~cm}) \text { and acceptable shape was recorded } \\
\left.\text { with hot air oven drying at } 40 \pm 1{ }^{\circ} \mathrm{C} \text {. Maximum percent moisture loss ( } 83.50\right) \text { was } \\
\text { observed with air drying under shade and microwave oven drying took minimum time for } \\
\text { drying }(0.03 \mathrm{~h}) \text {. Highest score for color }(2.20) \text {, texture }(2.65) \text {, brittleness }(3.40) \text { and overall } \\
\text { acceptability ( } 2.11) \text { was recorded when the flowers of carnation were dried in hot air oven } \\
\text { at } 55 \pm 1{ }^{\circ} \mathrm{C} \text {. }\end{array}$} \\
\hline Keywords & \\
\hline $\begin{array}{l}\text { Carnation, Drying } \\
\text { methods, Hot air } \\
\text { oven drying, } \\
\text { Sensory score. }\end{array}$ & \\
\hline Article Info & \\
\hline $\begin{array}{l}\text { Accepted: } \\
\text { 14 June } 2017 \\
\text { Available Online: } \\
10 \text { August } 2017\end{array}$ & \\
\hline & \\
\hline
\end{tabular}

\section{Introduction}

Flowers are closely associated with mankind from the dawn of civilization. The scope of utility and importance of flowers have been realized throughout the world and in this modern age, floriculture has developed into a profitable industry. Fresh flowers and foliages though exquisite in their beauty, are highly expensive. Also they are perishable and delicate in nature and cannot retain their beauty and fresh look for a long time inspite of using best chemicals for enhancing vase life. Moreover, there is a non-availability of fresh flowers and foliages all round the year in all places. In this context, flowers can be dried, preserved and processed to retain its beauty as well as everlasting value. Dried and preserved ornamental products offer a wide range of qualities like novelty, longevity, aesthetic properties, flexibility and year round availability. Dried ornamental plant parts are generally less expensive and are sought for their everlasting and attractive appearance. Drying of flowers and foliage by various methods like air drying, sun drying oven and microwave oven drying, freeze drying and embedded drying can be used for making 
decorative floral segments like wall hangings, landscape calenders, potpourries etc for various purposes. The growing demand for dry flowers is increasing day by day due to change in purchasing power and living habit of the human being in the world. However, in India, we have never looked into the tremendous export potential of dry flower industry and till date it is the most neglected industry. In the recent floriculture trade, the export of dry flowers from India during 201314 was Rs. 363.3 crores (Perinban et al., 2014). There is an unlimited prospect in this field and only with sustained efforts, we can make a significant presence in the world market. So there is a need to tune the techniques of drying of flowers with special reference to the available flora and fauna under the conditions prevailing in India. Carnation in modern times has become one of the most important cut flower crops. But, very little organized research work was done in carnation flowers for production of dry flowers. Keeping in view the above points, the present study on dehydration of carnation flowers was carried out with the objective of evaluating different drying methods for production of better quality carnation flowers with borax + silica gel $(1: 1, \mathrm{v} / \mathrm{v})$ mixture as the embedding medium.

\section{Materials and Methods}

The experiment was carried out at College of Horticulture, Rajendranagar, Hyderabad from August to November, 2014. In the present study, fourteen treatment combinations consisting of two carnation cultivars viz., Gaudina (red) and Harvey (yellow) and seven drying treatments $\left(\mathrm{T}_{1}\right.$ - Air drying under shade, $\mathrm{T}_{2}$ - Embedded drying in sun, $\mathrm{T}_{3}$ Embedded hot air oven drying at $40 \pm 1{ }^{\circ} \mathrm{C}, \mathrm{T}_{4}$ - Embedded hot air oven drying at $45 \pm 1^{\circ} \mathrm{C}$, $\mathrm{T}_{5}$ - Embedded hot air oven drying at $50 \pm$ $1^{\circ} \mathrm{C}, \mathrm{T}_{6}-$ Embedded hot air oven drying at 55 $\pm 1^{\circ} \mathrm{C}$ and $\mathrm{T}_{7}-$ Embedded microwave oven microwave drying) were evaluated in Factorial Completely Randomized Design with three replications. The healthy, disease free and uniform flower stems of carnation cultivars Gaudina and Harvey were harvested at the commercial stage (ray florets $3 / 4^{\text {th }}$ opened) in the morning hours between 8.00 and $9.00 \mathrm{am}$. Immediately after harvest, the cut ends of the flower stalks were placed in distilled water and brought to the laboratory of the department. The stem length of the each flower was kept at a uniform length of 6 $\mathrm{cm}$. The leaves present on each cut stem were removed before using them for drying. For air drying under shade, the flowers were tied using a thread and hung upside down in a warm, dry room with good air circulation. For the embedded sun and hot air oven drying, plastic containers $(14 \mathrm{~cm}$ height and $14 \mathrm{~cm}$ diameter) with lid were used. For microwave oven drying, glass beakers were used. About one inch layer of the desiccant viz., borax + silica gel $(1: 1, \mathrm{v} / \mathrm{v})$ mixture was poured into the bottom of container and the flower stems were pushed into the medium. Desiccant was then gently and gradually poured all around and over the flower up to 4 to $5 \mathrm{~cm}$ above, so as to fill all the crevices in between the petals without disturbing the shape of flowers. In case of sun drying, the containers were kept in sun daily to facilitate rapid dehydration. During evening hours the containers were shifted under roof. For hot air oven drying of flowers, containers were kept in electrically operated hot air oven at different temperature levels $\left(40 \pm 1{ }^{\circ} \mathrm{C}, 45 \pm 1{ }^{\circ} \mathrm{C}, 50 \pm 1{ }^{\circ} \mathrm{C}\right.$ and $55 \pm$ $1{ }^{\circ} \mathrm{C}$ ). For microwave oven drying, the glass beakers were kept in microwave oven till flowers were dried. After drying of the flowers, the containers were taken out and kept at ambient temperature for about $3 \mathrm{~h}$ (setting time) without disturbing, so that the moisture content of the desiccant in the containers gets evaporated. In all the methods of embedded drying, after dehydration the containers were tilted for removing the 
desiccants over and around the flowers. The dried flowers were picked up by hand, cleaned by inverting them and tapping the stems with fingers slowly and gently. Remaining desiccant was finally removed with the help of fine brush. Observations on flower fresh weight, dry weight, dry flower diameter, per cent moisture loss and time taken to dry were recorded. A panel of five judges assessed the quality parameters viz., color, shape, texture, brittleness and overall acceptability by scoring on a five-point scale i.e. excellent, very good, good, bad and very bad with the weightage of 3.5-4.0, 2.5-3.4, 1.5-2.4, 0.5-1.4 and 0.0-0.4 respectively. The data were analyzed using factorial CRD (Panse and Sukhatme, 1985).

\section{Results and Discussion}

The flowers used for the experiment did not vary with respect to fresh weight, due to uniform flowers used in the experiment. The data pertaining to carnation dry flower weight as influenced by the cultivars and methods of drying is presented in table 1. Among the cultivars, Gaudina recorded maximum dry flower weight $(1.51 \mathrm{~g})$ than $\mathrm{cv}$. Harvey (1.48 g). This may be mainly due to inherent varietal variation. Methods of drying showed significant effect on dry flower weight. Maximum dry flower weight was recorded with hot air oven drying at $40 \pm 1{ }^{\circ} \mathrm{C}(2.19 \mathrm{~g})$ followed by hot air oven drying at $45 \pm 1{ }^{\circ} \mathrm{C}$ $(1.48 \mathrm{~g})$. The dry weight of carnation flowers was decreased gradually in all desiccants tried as the temperature of the hot air oven increased from $40^{\circ} \mathrm{C}$ to $55^{\circ} \mathrm{C}$. This might be due to liberation of less water at low temperature as there is direct relationship between temperature and moisture loss. Similar results were found by Sangama (2004) in helichrysum flowers and Singh et al., (2004) in zinnia. Minimum dry flower weight was observed with air drying method under shade $(1.23 \mathrm{~g})$. This was because of direct exposure of flowers to different microclimatic conditions leading to rapid water loss. These results were in accordance with Dhatt et al., (2007) in rose buds. With respect to the interactions, significantly maximum dry flower weight was recorded with the flowers of cv. Gaudina dried in hot air oven at $40 \pm 1{ }^{\circ} \mathrm{C}(2.33 \mathrm{~g})$ followed by the cv. Harvey dried in hot air oven at $40 \pm 1^{\circ} \mathrm{C}$ (2.06 g), while minimum dry flower weight was observed when flowers of cv. Harvey dried with air drying under shade (1.22 g) and was on par with cv. Gaudina dried with air drying under shade (1.24 g).

A perusal of data on carnation dry flower diameter (Table 2) revealed that among the cultivars, significantly maximum dry flower diameter was observed with 'Gaudina' (3.47 $\mathrm{cm})$ when compared to 'Harvey' $(3.24 \mathrm{~cm})$. This might be owing to its varietal character. There were significant differences on dry flower diameter due to different methods of drying. Maximum dry flower diameter was recorded when the flowers were dried in hot air oven at $40 \pm 1{ }^{\circ} \mathrm{C}(4.07 \mathrm{~cm})$ followed by hot air oven drying at $45 \pm 1{ }^{\circ} \mathrm{C}(3.57 \mathrm{~cm})$. This is because at low temperature, the moisture is removed in a steady rate without affecting structural integrity of flowers and thus flower shape will be retained. These results were in accordance with Nair et al., (2011) in chrysanthemum flowers. Minimum dry flower diameter was observed with air drying method under shade $(2.34 \mathrm{~cm})$. This might be due to maximum removal of moisture from flowers. The interaction effect between the cultivars and different methods of drying was found significant. Maximum dry flower diameter was recorded with cv. Gaudina dried in hot air oven at $40 \pm 1{ }^{\circ} \mathrm{C}$ $(4.11 \mathrm{~cm})$ and was on par with cv. Harvey dried in hot air oven at $40 \pm 1{ }^{\circ} \mathrm{C}(4.04 \mathrm{~cm})$, while the minimum dry flower diameter was recorded when flowers of cv. Harvey were dried by air drying method under shade (2.29 
$\mathrm{cm})$ and was on par with cv. Gaudina dried in air drying method under shade $(2.40 \mathrm{~cm})$. Susan (2004) reported that air drying is the easiest and low cost method of preserving flowers and foliage but causes flowers to shrink.

The per cent moisture loss in carnation flowers due to cultivars and methods of drying is presented in table 3. Among the cultivars, cv. Harvey recorded maximum per cent moisture loss (76.70) when compared to the cv. Gaudina (75.93). Significantly maximum per cent moisture loss was recorded with air drying under shade (83.50) and was on par with hot air oven drying at 55 $\pm 1^{\circ} \mathrm{C}$ (81.76). This is because direct exposure of flowers to different microclimatic conditions leads to rapid water loss and at higher temperature of the oven, the rate of moisture loss from flower tissues was more due to more conduction and convection of heat to flower tissue and water evaporation from the surface. Least moisture loss was observed with hot air oven drying at $40 \pm 1{ }^{\circ} \mathrm{C}$ (66.04). With respect to interactions, cv. Gaudina lost maximum of moisture when dried in air under shade (87.02) followed by flowers of cv. Harvey dried in hot air oven at $55 \pm 1{ }^{\circ} \mathrm{C}$ (81.87). Minimum per cent moisture loss was recorded when flowers of $\mathrm{cv}$. Gaudina dried in hot air oven at $40 \pm 1{ }^{\circ} \mathrm{C}$ (62.29). These results were in accordance with Dhatt et al., (2007) in rose buds.

The time taken for drying of carnation flowers was significantly influenced by the cultivars (Table 4). Cv. Least time for drying was taken by the cv. Harvey $(60.29 \mathrm{~h})$ than the $\mathrm{cv}$. Gaudina $(91.10 \mathrm{~h})$. Among the different methods of drying, significantly least time for drying of flowers was recorded with microwave oven $(0.03 \mathrm{~h})$. This might be due to quick release of maximum amount of moisture by agitating water molecules with the help of electronically produced microwaves. These results are in line with the reports of Safeena and Patil (2013) in rose and Jagadeesh et al., (2014) in gerbera. Maximum time for drying of flowers was recorded with air drying under shade (336.50 h). The interaction effects of carnation cultivars and drying methods on time time taken to dry were found significant. Flowers of cv. Harvey took least time for drying with microwave oven $(0.02 \mathrm{~h})$ followed by the flowers of cv. Gaudina dried in microwave oven $(0.03 \mathrm{~h})$, while the maximum time taken for drying was observed when the flowers of cv. Gaudina dried in air under shade (420.66 h).

The data on colour of dried carnation flowers (Table 5) showed that the cv. Harvey had retained good colour and received the maximum score of 1.85 when compared to the cv. Gaudina (0.62). Significantly maximum score for colour was recorded when the flower of carnation were dried in hot air oven at $55 \pm 1{ }^{\circ} \mathrm{C}$ (2. 20) followed by flowers dried in sun (1.78). Least score for colour was observed when flowers of carnation were dried under shade with air drying method (0.28). The interaction effect of cultivars and methods of drying on colour was found significant. Maximum score for colour was recorded when flowers of $\mathrm{cv}$. Harvey dried in hot air oven at $55 \pm 1{ }^{\circ} \mathrm{C}$ (3.50) followed by flowers of cv. Harvey dried in sun (2.83), while the least score for colour was recorded with cv. Gaudina dried with air drying method (0.26) and was on par with cv. Harvey with air drying method (0.30). The results are in line with those of Joykumar (1997) who reported that colour of dried flowers of rose, aster and chrysanthemum were good in oven drying with silica gel as embedding medium. Peggy (1978) reported silica gel as the most appropriate dessicant for proper retention of colour. Venugopal and Patil (2000) reported that helichrysum flowers dried at $50^{\circ} \mathrm{C}$ in 
oven for $48 \mathrm{~h}$ were found to retain good colour for 150-180 days. The present study revealed that Gaudina cultivar lost colour after drying. It might be due to bleaching reaction of flower colour to drying method and media or due to varietal character. These results are also in accordance with Safeena and Patil (2013) in First Red cultivar of rose. The least score for colour was observed in air drying might be due to colour fading due to direct exposure of flowers to different microclimatic conditions. Similar results were found by Kumari and Peiris (2000).

The sensory scores for shape as influenced by the cultivars and methods of drying is presented in table 6. Among the cultivars, Harvey recorded significantly maximum score for shape (2.71) than the cv. Gaudina (2.52). Significantly maximum score for shape was recorded when flowers of carnation dried in hot air oven at $40 \pm 1{ }^{\circ} \mathrm{C}$ (3.60) followed by hot air oven drying at $45 \pm 1{ }^{\circ} \mathrm{C}$ (3.31). Least score for shape was recorded with air drying under shade (0.26). The interactions between the cultivars and methods of drying were found nonsignificant. The observations from the table 6 confirm that maximum score for shape was recorded with the flowers of cv. Harvey and hot air oven drying at $40 \pm 1{ }^{\circ} \mathrm{C}$. This might be due to removal of moisture in a steady rate without affecting the structural integrity of flowers. Kher and Bhutani (1979) reported that flowers embedded in silica gel remained intact throughout the drying process and also maintained the original shape. Venugopal and Patil (2000) reported that helichrysum flowers dried at $50^{\circ} \mathrm{C}$ in oven for $48 \mathrm{~h}$ were found to retain shape for 150-180 days. Aravinda and Jayanthi (2004) observed that chrysanthemum flowers embedded in silica gel retained their shape after drying. Rajesh et al., (2006) reported that silica gel embedding of chrysanthemum flowers resulted in high quality flowers and better retention of flower size. Nair et al., (2011) reported that when flowers of chrysanthemum embedded in silica gel and dried in oven at $40^{\circ} \mathrm{C}$ and $50^{\circ} \mathrm{C}$ recorded minimum size reduction. Least score for shape was recorded with air drying method. It might be due to rapid loss of water resulting in shrinkage of petals. Kumari and Peiris (2000) reported that air drying in rose resulted in loss of shape.

Significant differences were observed due to cultivars and methods of drying with respect to texture of dried carnation flowers (Table $7)$. The cv. Harvey recorded maximum score for texture (2.06) when compared to the cv. Gaudina (1.33). Maximum textural score was recorded when flowers of carnation dried in hot air oven at $55 \pm 1{ }^{\circ} \mathrm{C}$ (2.65) followed by flowers dried in sun (2.11). The least score for texture was recorded with air drying under shade (0.31). Interaction effect between cultivars and methods of drying on texture was also observed to be significant. Maximum textural score was recorded when the flowers of carnation cv. Harvey were dried in hot air oven at $55 \pm 1{ }^{\circ} \mathrm{C}$ (3.56) followed by the flowers of cv. Harvey dried in sun (2.56), while the least score for texture was recorded when flowers of cv. Gaudina were dried with air drying method (0.20). Joy kumar (1997) reported that smooth petal texture was observed in China aster and chrysanthemum flowers when embedded in silica gel and dried in hot air oven. These results were also in accordance with Nair and Singh (2011) in chrysanthemum and Safeena and Patil (2013) in 'Lambada' cultivar of rose. The brittleness of dry carnation flower did not differ significantly due to cultivars (Table 8). Methods of drying and interaction of cultivars and methods of drying showed significant differences. Maximum score for brittleness was observed when the flowers of carnation were dried in hot air oven at $55 \pm$ $1^{\circ} \mathrm{C}$ (3.40) followed by embedded sun drying method (2.75). 
Table.1 Effect of methods of drying on dry flower weight $(\mathrm{g})$ in carnation cultivars Gaudina and Harvey

\begin{tabular}{|c|c|c|c|}
\hline \multirow[b]{2}{*}{ Treatments $(\mathbf{T})$} & \multicolumn{2}{|c|}{ Cultivars (C) } & \multirow[b]{2}{*}{ Mean } \\
\hline & $\begin{array}{c}\text { Gaudina } \\
\left(\mathbf{C}_{1}\right)\end{array}$ & $\begin{array}{c}\text { Harvey } \\
\left(C_{2}\right)\end{array}$ & \\
\hline $\mathrm{T}_{1}$ - Air drying under shade & 1.24 & 1.22 & 1.23 \\
\hline$T_{2}$ - Embedded drying in sun & 1.36 & 1.42 & 1.39 \\
\hline $\begin{array}{l}\mathrm{T}_{3} \text { - Embedded hot air oven drying } \\
\text { at } 40 \pm 1{ }^{\circ} \mathrm{C}\end{array}$ & 2.33 & 2.06 & 2.19 \\
\hline $\begin{array}{l}\mathrm{T}_{4}-\text { Embedded hot air oven drying at } \\
\quad 45 \pm 1{ }^{\circ} \mathrm{C}\end{array}$ & 1.52 & 1.44 & 1.48 \\
\hline $\begin{array}{l}\mathrm{T}_{5} \text { - Embedded hot air oven drying at } \\
50 \pm 1{ }^{\circ} \mathrm{C}\end{array}$ & 1.38 & 1.40 & 1.39 \\
\hline $\begin{array}{l}\mathrm{T}_{6} \text { - Embedded hot air oven drying at } \\
55 \pm 1{ }^{\circ} \mathrm{C}\end{array}$ & 1.31 & 1.39 & 1.35 \\
\hline $\begin{array}{l}\mathrm{T}_{7} \text { - Embedded microwave oven } \\
\text { drying. }\end{array}$ & 1.45 & 1.43 & 1.44 \\
\hline Mean & 1.51 & 1.48 & \\
\hline
\end{tabular}

\begin{tabular}{|l|c|c|}
\hline & S.Em \pm & CD at 5\% \\
\hline Cultivars (C) & 0.01 & 0.03 \\
\hline Treatments (T) & 0.01 & 0.05 \\
\hline Interaction (CXT) & 0.02 & 0.07 \\
\hline
\end{tabular}

Table.2 Effect of methods of drying on dry flower diameter $(\mathrm{cm})$ in carnation cultivars Gaudina and Harvey

\begin{tabular}{|c|c|c|c|}
\hline \multirow[b]{2}{*}{ Treatments (T) } & \multicolumn{2}{|c|}{ Cultivars (C) } & \multirow[b]{2}{*}{ Mean } \\
\hline & $\begin{array}{l}\text { Gaudina } \\
\left(\mathbf{C}_{1}\right)\end{array}$ & $\begin{array}{l}\text { Harvey } \\
\left(C_{2}\right)\end{array}$ & \\
\hline$T_{1}$ - Air drying under shade & 2.40 & 2.29 & 2.34 \\
\hline$T_{2}-$ Embedded drying in sun & 3.53 & 3.14 & 3.34 \\
\hline $\begin{array}{l}\mathrm{T}_{3} \text { - Embedded hot air oven drying } \\
\text { at } 40 \pm 1^{\circ} \mathrm{C}\end{array}$ & 4.11 & 4.04 & 4.07 \\
\hline $\begin{array}{l}\mathrm{T}_{4} \text { - Embedded hot air oven drying at } \\
\quad 45 \pm 1^{\circ} \mathrm{C}\end{array}$ & 3.62 & 3.53 & 3.57 \\
\hline $\begin{array}{l}\mathrm{T}_{5} \text { - Embedded hot air oven drying at } \\
50 \pm 1^{\circ} \mathrm{C}\end{array}$ & 3.57 & 3.21 & 3.39 \\
\hline
\end{tabular}




\begin{tabular}{|l|c|c|c|}
\hline $\begin{array}{l}\mathrm{T}_{6}-\text { Embedded hot air oven drying at } \\
55 \pm 1^{\circ} \mathrm{C}\end{array}$ & 3.51 & 3.00 & 3.25 \\
\hline $\begin{array}{l}\mathrm{T}_{7}-\text { Embedded microwave oven } \\
\text { drying. }\end{array}$ & 3.60 & 3.46 & 3.53 \\
\hline Mean & 3.47 & 3.24 & \\
\hline
\end{tabular}

\begin{tabular}{|l|c|c|}
\hline & S.Em \pm & CD at 5\% \\
\hline Cultivars (C) & 0.01 & 0.04 \\
\hline Treatments (T) & 0.03 & 0.08 \\
\hline Interaction (CXT) & 0.04 & 0.12 \\
\hline
\end{tabular}

Table.3 Effect of methods of drying on percent moisture loss (\%) in carnation cultivars Gaudina and Harvey

\begin{tabular}{|c|c|c|c|}
\hline \multirow[b]{2}{*}{ Treatments $(\mathbf{T})$} & \multicolumn{2}{|c|}{ Cultivars (C) } & \multirow[b]{2}{*}{ Mean } \\
\hline & $\begin{array}{c}\text { Gaudina } \\
\left(\mathbf{C}_{1}\right)\end{array}$ & $\begin{array}{c}\text { Harvey } \\
\left(\mathrm{C}_{2}\right)\end{array}$ & \\
\hline $\mathrm{T}_{1}$ - Air drying under shade & 87.02 & 79.98 & 83.50 \\
\hline $\mathrm{T}_{2}-$ Embedded drying in sun & 77.11 & 81.04 & 79.08 \\
\hline $\begin{array}{l}\mathrm{T}_{3} \text { - Embedded hot air oven drying } \\
\text { at } 40 \pm 1^{\circ} \mathrm{C}\end{array}$ & 62.29 & 69.80 & 66.04 \\
\hline $\begin{array}{l}\mathrm{T}_{4} \text { - Embedded hot air oven drying at } \\
45 \pm 1^{\circ} \mathrm{C}\end{array}$ & 71.24 & 72.22 & 71.73 \\
\hline $\begin{array}{l}\mathrm{T}_{5}-\text { Embedded hot air oven drying at } \\
50 \pm 1^{\circ} \mathrm{C}\end{array}$ & 76.33 & 74.47 & 75.40 \\
\hline $\begin{array}{l}\mathrm{T}_{6}-\text { Embedded hot air oven drying at } \\
55 \pm 1{ }^{\circ} \mathrm{C}\end{array}$ & 81.64 & 81.87 & 81.76 \\
\hline $\begin{array}{l}\mathrm{T}_{7}-\text { Embedded microwave oven } \\
\text { drying. }\end{array}$ & 75.88 & 77.54 & 76.71 \\
\hline Mean & 75.93 & 76.70 & \\
\hline
\end{tabular}

\begin{tabular}{|l|c|c|}
\hline & S.Em \pm & CD at 5\% \\
\hline Cultivars (C) & 0.23 & 0.67 \\
\hline Treatments (T) & 0.43 & 1.26 \\
\hline Interaction (CXT) & 0.61 & 1.79 \\
\hline
\end{tabular}


Table.4 Effect of methods of drying on time taken to dry (hours) in carnation cultivars Gaudina and Harvey

\begin{tabular}{|c|c|c|c|}
\hline \multirow[b]{2}{*}{ Treatments $(\mathbf{T})$} & \multicolumn{2}{|c|}{ Cultivars (C) } & \multirow[b]{2}{*}{ Mean } \\
\hline & $\begin{array}{c}\text { Gaudina } \\
\left(\mathbf{C}_{1}\right)\end{array}$ & $\begin{array}{l}\text { Harvey } \\
\left(\mathrm{C}_{2}\right)\end{array}$ & \\
\hline $\mathrm{T}_{1}$ - Air drying under shade & 420.66 & 252.33 & 336.50 \\
\hline $\mathrm{T}_{2}-$ Embedded drying in sun & 38.33 & 29.00 & 33.66 \\
\hline $\begin{array}{l}\mathrm{T}_{3} \text { - Embedded hot air oven drying } \\
\text { at } 40 \pm 1{ }^{\circ} \mathrm{C}\end{array}$ & 53.00 & 44.33 & 48.66 \\
\hline $\begin{array}{l}\mathrm{T}_{4}-\text { Embedded hot air oven drying at } \\
45 \pm 1^{\circ} \mathrm{C}\end{array}$ & 51.00 & 41.00 & 46.00 \\
\hline $\begin{array}{l}\mathrm{T}_{5}-\text { Embedded hot air oven drying at } \\
50 \pm 1^{\circ} \mathrm{C}\end{array}$ & 44.00 & 32.33 & 38.16 \\
\hline $\begin{array}{l}\mathrm{T}_{6}-\text { Embedded hot air oven drying at } \\
55 \pm 1^{\circ} \mathrm{C}\end{array}$ & 30.66 & 23.00 & 26.83 \\
\hline $\begin{array}{l}\mathrm{T}_{7}-\text { Embedded microwave oven } \\
\text { drying. }\end{array}$ & 0.03 & 0.02 & 0.03 \\
\hline Mean & 91.10 & 60.29 & \\
\hline & \multicolumn{2}{|c|}{ S.Em \pm} & CD at $5 \%$ \\
\hline Cultivars (C) & \multicolumn{2}{|l|}{0.97} & 2.84 \\
\hline Treatments (T) & \multicolumn{2}{|l|}{1.82} & 5.32 \\
\hline Interaction (CXT) & \multicolumn{2}{|l|}{2.58} & 7.53 \\
\hline
\end{tabular}

Table.5 Effect of methods of drying on colour of dried carnation cultivars Gaudina and Harvey as assessed through sensory evaluation

\begin{tabular}{|c|c|c|c|}
\hline \multirow[b]{2}{*}{ Treatments (T) } & \multicolumn{2}{|c|}{ Cultivars (C) } & \multirow[b]{2}{*}{ Mean } \\
\hline & $\begin{array}{c}\text { Gaudina } \\
\left(\mathbf{C}_{1}\right)\end{array}$ & $\begin{array}{c}\text { Harvey } \\
\left(\mathrm{C}_{2}\right)\end{array}$ & \\
\hline $\mathrm{T}_{1}$ - Air drying under shade & 0.26 & 0.30 & 0.28 \\
\hline $\mathrm{T}_{2}-$ Embedded drying in sun & 0.73 & 2.83 & 1.78 \\
\hline $\begin{array}{l}\mathrm{T}_{3} \text { - Embedded hot air oven drying } \\
\text { at } 40 \pm 1^{\circ} \mathrm{C}\end{array}$ & 0.60 & 1.80 & 1.20 \\
\hline $\begin{array}{l}\mathrm{T}_{4}-\text { Embedded hot air oven drying at } \\
\quad 45 \pm 1^{\circ} \mathrm{C}\end{array}$ & 0.63 & 1.83 & 1.23 \\
\hline $\begin{array}{l}\mathrm{T}_{5}-\text { Embedded hot air oven drying at } \\
50 \pm 1^{\circ} \mathrm{C}\end{array}$ & 0.70 & 1.86 & 1.28 \\
\hline $\begin{array}{l}\mathrm{T}_{6}-\text { Embedded hot air oven drying at } \\
55 \pm 1^{\circ} \mathrm{C}\end{array}$ & 0.90 & 3.50 & 2.20 \\
\hline
\end{tabular}




\begin{tabular}{|l|l|l|l|}
\hline $\begin{array}{l}\mathrm{T}_{7} \text { - Embedded microwave oven } \\
\text { drying. }\end{array}$ & 0.53 & 0.86 & 0.70 \\
\hline Mean & 0.62 & 1.85 & \\
\hline
\end{tabular}

\begin{tabular}{|l|c|c|}
\hline & S.Em \pm & CD at 5\% \\
\hline Cultivars (C) & 0.02 & 0.06 \\
\hline Treatments (T) & 0.04 & 0.13 \\
\hline Interaction (CXT) & 0.06 & 0.18 \\
\hline
\end{tabular}

Table.6 Effect of methods of drying on shape of dried carnation cultivars Gaudina and Harvey as assessed through sensory evaluation

\begin{tabular}{|c|c|c|c|}
\hline \multirow[b]{2}{*}{ Treatments $(\mathbf{T})$} & \multicolumn{2}{|c|}{ Cultivars (C) } & \multirow[b]{2}{*}{ Mean } \\
\hline & $\begin{array}{c}\text { Gaudina } \\
\left(\mathbf{C}_{1}\right)\end{array}$ & $\begin{array}{c}\text { Harvey } \\
\left(C_{2}\right)\end{array}$ & \\
\hline$T_{1}-$ Air drying under shade & 0.23 & 0.30 & 0.26 \\
\hline $\mathrm{T}_{2}$ - Embedded drying in sun & 2.46 & 2.60 & 2.53 \\
\hline $\begin{array}{l}\mathrm{T}_{3} \text { - Embedded hot air oven drying } \\
\text { at } 40 \pm 1{ }^{\circ} \mathrm{C}\end{array}$ & 3.56 & 3.63 & 3.60 \\
\hline $\begin{array}{l}\mathrm{T}_{4} \text { - Embedded hot air oven drying at } \\
\quad 45 \pm 1^{\circ} \mathrm{C}\end{array}$ & 3.20 & 3.43 & 3.31 \\
\hline $\begin{array}{l}\mathrm{T}_{5} \text { - Embedded hot air oven drying at } \\
50 \pm 1{ }^{\circ} \mathrm{C}\end{array}$ & 2.90 & 3.20 & 3.05 \\
\hline $\begin{array}{l}\mathrm{T}_{6}-\text { Embedded hot air oven drying at } \\
55 \pm 1{ }^{\circ} \mathrm{C}\end{array}$ & 2.80 & 3.03 & 2.91 \\
\hline $\begin{array}{l}\mathrm{T}_{7}-\text { Embedded microwave oven } \\
\text { drying. }\end{array}$ & 2.50 & 2.80 & 2.65 \\
\hline Mean & 2.52 & 2.71 & \\
\hline
\end{tabular}

\begin{tabular}{|l|c|c|}
\hline & S.Em \pm & CD at 5\% \\
\hline Cultivars (C) & 0.02 & 0.06 \\
\hline Treatments (T) & 0.03 & 0.11 \\
\hline Interaction (CXT) & 0.05 & NS \\
\hline
\end{tabular}


Table.7 Effect of methods of drying on texture of dried carnation cultivars Gaudina and Harvey as assessed through sensory evaluation

\begin{tabular}{|c|c|c|c|}
\hline \multirow[b]{2}{*}{ Treatments $(T)$} & \multicolumn{2}{|c|}{ Cultivars (C) } & \multirow[b]{2}{*}{ Mean } \\
\hline & $\begin{array}{c}\text { Gaudina } \\
\left(\mathbf{C}_{1}\right) \\
\end{array}$ & $\begin{array}{c}\text { Harvey } \\
\left(\mathrm{C}_{2}\right)\end{array}$ & \\
\hline $\mathrm{T}_{1}$ - Air drying under shade & 0.20 & 0.43 & 0.31 \\
\hline $\mathrm{T}_{2}-$ Embedded drying in sun & 1.66 & 2.56 & 2.11 \\
\hline $\begin{array}{l}\mathrm{T}_{3} \text { - Embedded hot air oven drying } \\
\text { at } 40 \pm 1{ }^{\circ} \mathrm{C}\end{array}$ & 1.50 & 1.90 & 1.70 \\
\hline $\begin{array}{l}\mathrm{T}_{4} \text { - Embedded hot air oven drying at } \\
\quad 45 \pm 1{ }^{\circ} \mathrm{C}\end{array}$ & 1.53 & 2.13 & 1.83 \\
\hline $\begin{array}{l}\mathrm{T}_{5}-\text { Embedded hot air oven drying at } \\
50 \pm 1{ }^{\circ} \mathrm{C}\end{array}$ & 1.56 & 2.36 & 1.96 \\
\hline $\begin{array}{l}\mathrm{T}_{6}-\text { Embedded hot air oven drying at } \\
55 \pm 1^{\circ} \mathrm{C}\end{array}$ & 1.73 & 3.56 & 2.65 \\
\hline $\begin{array}{l}\mathrm{T}_{7}-\text { Embedded microwave oven } \\
\text { drying. }\end{array}$ & 1.13 & 1.50 & 1.31 \\
\hline Mean & 1.33 & 2.06 & \\
\hline & S.Em \pm & & CD at $5 \%$ \\
\hline Cultivars (C) & 0.02 & & 0.06 \\
\hline Treatments $(\mathrm{T})$ & 0.04 & & 0.12 \\
\hline Interaction (CXT) & 0.06 & & 0.17 \\
\hline
\end{tabular}

Table.8 Effect of methods of drying on brittleness of dried carnation cultivars Gaudina and Harvey as assessed through sensory evaluation

\begin{tabular}{|c|c|c|c|}
\hline \multirow[b]{2}{*}{ Treatments $(\mathbf{T})$} & \multicolumn{2}{|c|}{ Cultivars (C) } & \multirow[b]{2}{*}{ Mean } \\
\hline & $\begin{array}{c}\text { Gaudina } \\
\left(\mathbf{C}_{1}\right)\end{array}$ & $\begin{array}{c}\text { Harvey } \\
\left(\mathrm{C}_{2}\right)\end{array}$ & \\
\hline $\mathrm{T}_{1}$ - Air drying under shade & 0.20 & 0.26 & 0.23 \\
\hline $\mathrm{T}_{2}-$ Embedded drying in sun & 2.96 & 2.53 & 2.75 \\
\hline $\begin{array}{l}\mathrm{T}_{3} \text { - Embedded hot air oven drying } \\
\text { at } 40 \pm 1{ }^{\circ} \mathrm{C}\end{array}$ & 2.00 & 2.10 & 2.05 \\
\hline $\begin{array}{l}\mathrm{T}_{4} \text { - Embedded hot air oven drying at } \\
45 \pm 1{ }^{\circ} \mathrm{C}\end{array}$ & 2.03 & 2.26 & 2.15 \\
\hline $\begin{array}{l}\mathrm{T}_{5}-\text { Embedded hot air oven drying at } \\
50 \pm 1^{\circ} \mathrm{C}\end{array}$ & 2.06 & 2.40 & 2.23 \\
\hline $\begin{array}{l}\mathrm{T}_{6} \text { - Embedded hot air oven drying at } \\
55 \pm 1^{\circ} \mathrm{C}\end{array}$ & 3.43 & 3.36 & 3.40 \\
\hline
\end{tabular}




\begin{tabular}{|l|c|c|c|}
\hline $\begin{array}{l}\mathrm{T}_{7}-\text { Embedded microwave oven } \\
\text { drying. }\end{array}$ & 1.76 & 1.83 & 1.80 \\
\hline Mean & 2.06 & 2.11 & \\
\hline
\end{tabular}

\begin{tabular}{|l|c|c|}
\hline & S.Em \pm & CD at 5\% \\
\hline Cultivars (C) & 0.03 & N.S \\
\hline Treatments (T) & 0.05 & 0.17 \\
\hline Interaction (CXT) & 0.08 & 0.24 \\
\hline
\end{tabular}

Table.9 Effect of methods of drying on overall acceptability of dried carnation cultivars Gaudina and Harvey as assessed through sensory evaluation

\begin{tabular}{|c|c|c|c|}
\hline \multirow[b]{2}{*}{ Treatments $(\mathbf{T})$} & \multicolumn{2}{|c|}{ Cultivars (C) } & \multirow[b]{2}{*}{ Mean } \\
\hline & $\begin{array}{c}\text { Gaudina } \\
\left(\mathbf{C}_{1}\right)\end{array}$ & $\begin{array}{c}\text { Harvey } \\
\left(\mathrm{C}_{2}\right)\end{array}$ & \\
\hline $\mathrm{T}_{1}$ - Air drying under shade & 0.70 & 0.90 & 0.80 \\
\hline $\mathrm{T}_{2}-$ Embedded drying in sun & 0.56 & 2.46 & 1.51 \\
\hline $\begin{array}{l}\mathrm{T}_{3} \text { - Embedded hot air oven drying } \\
\text { at } 40 \pm 1^{\circ} \mathrm{C}\end{array}$ & 0.46 & 2.20 & 1.33 \\
\hline $\begin{array}{l}\mathrm{T}_{4} \text { - Embedded hot air oven drying at } \\
45 \pm 1^{\circ} \mathrm{C}\end{array}$ & 0.50 & 2.40 & 1.45 \\
\hline $\begin{array}{l}\mathrm{T}_{5}-\text { Embedded hot air oven drying at } \\
50 \pm 1^{\circ} \mathrm{C}\end{array}$ & 0.53 & 2.40 & 1.46 \\
\hline $\begin{array}{l}\mathrm{T}_{6}-\text { Embedded hot air oven drying at } \\
55 \pm 1^{\circ} \mathrm{C}\end{array}$ & 0.66 & 3.56 & 2.11 \\
\hline $\begin{array}{l}\mathrm{T}_{7}-\text { Embedded microwave oven } \\
\text { drying. }\end{array}$ & 0.40 & 1.90 & 1.15 \\
\hline Mean & 0.54 & 2.26 & \\
\hline
\end{tabular}

\begin{tabular}{|l|c|c|}
\hline & S.Em \pm & CD at 5\% \\
\hline Cultivars (C) & 0.02 & 0.07 \\
\hline Treatments (T) & 0.05 & 0.14 \\
\hline Interaction (CXT) & 0.07 & 0.20 \\
\hline
\end{tabular}

These results were in accordance with Dilta et al., (2014) who showed that the flowers of rose cv. First Red embedded in borax and dried in oven recorded minimum flower brittleness mainly due to slow heating effect of borax. The least score for brittleness was recorded with air drying method (0.23). Among the interactions, flowers of cv. Gaudina dried in hot air oven at $55 \pm 1{ }^{\circ} \mathrm{C}$
(3.43) scored maximum points and was found on par with cv. Harvey dried in hot air oven at $55 \pm 1{ }^{\circ} \mathrm{C}$ (3.36). Least score was recorded in the flowers of $\mathrm{cv}$. Gaudina dried with air drying method (0.20) and was on par with cv. Harvey dried with air drying method (0.26).

The data pertaining to overall acceptability of dried carnation flowers as influenced by the 
cultivars and methods of drying is presented in table 9. The data revealed that the cv. Harvey recorded maximum score for overall acceptability (2.26) when compared to the cv. Gaudina (0.54). Significant differences were observed on overall acceptability due to different methods of drying. Maximum sensory score was recorded with flowers dried in hot air oven at $55 \pm 1^{\circ} \mathrm{C}$ (2.11) followed by flowers dried in sun (1.51). Least score for overall acceptability (0.80) was observed with air drying method. Among the interactions, the flowers of the cv. Harvey dried in hot air oven at $55 \pm 1^{\circ} \mathrm{C}$ recorded maximum score of 3.56 followed by flowers of cv. Harvey dried in sun (2.46), while the least score of 0.40 for overall acceptability was recorded with cv. Gaudina dried in microwave oven. Rajesh et al., (2006) reported when flowers of chrysanthemum dried in hot air oven at $60^{\circ} \mathrm{C}$ treated with silica gel obtained maximum presentability score under covered conditions. Nair and Singh (2011) reported that flowers embedded in silica gel scored maximum points for good appearance when dried in hot air oven. Safeena and Patil (2013) reported that maximum score for dry flower appearance was recorded in cv. Lambada dried in hot air oven. Least score (0.40) was recorded when flowers of Gaudina dried in microwave oven. This might be attributed due to sticking of borax and silica gel to petals due to quick release of maximum amount of moisture by agitating water molecules with the help of electronically produced microwaves. From the present study, it could be concluded that hot air oven drying at $55 \pm$ $1{ }^{\circ} \mathrm{C}$ with silica gel + borax $(1: 1, \mathrm{v} / \mathrm{v})$ mixture as the embedding medium is best for production of quality dry flowers of carnation cv. Harvey.

\section{References}

Aravinda, K. and Jayanthi, R. 2004. Standardization of drying techniques for chrysanthemum (Dendranthema grandiflora Tzvelev cv. Button Type Local) flowers. J. Orn. Hort., 7: 370375.

Dhatt, K.K., Singh, K. and Ramesh, K. 2007. Studies on methods of dehydration of rose buds. J. Orn. Hort., 10: 264-267.

Dilta, B.S., Behera, T.B., Gupta, Y.C., Bhalla, R.B. and Sharma, P. 2014. Effect of embedding media, temperature and durations on hot air oven drying of rose (Rosa hybrid L.) cv. First Red. Ind. J. Appl. Res., 4: 233-239.

Jagadeesh, H., Ulla, H.M.T., Sajjan, M.R., Lokesh, K., Ramachandra, N. and Kumar, T.V. 2014. Effect of embedding media and drying methods on physicochemical parameters of dried gerbera cut flowers. Environ. Ecol., 32: 12071211.

Joykumar, N. 1997. Studies on the drying characteristics of some important flowers. M.Sc. (Agri.) thesis submitted to University of Agricultural Sciences, Bangalore.

Kher, M.A. and Bhutani, J.C. 1979. Dehydration of flowers and foliage. Extension Bulletin, NBRI, Lucknow: 120.

Kumari, D.L.C. and Peiris, S.E. 2000. Preliminary investigation of preservation methods to produce dried flowers of rose and statice. Tropical Agric. Res., 12: 416-422.

Nair, B., Krishna, P.S. and Vidhya Sankar, M. 2011. Effect of different temperatures and dessicants on quality of yellow button type chrysanthemum flowers. Jawaharlal Nehru Krishi Vishwa Vidyalaya Res. J., 45: 172-174.

Nair, B. and Singh, K.P. 2011. Aesthetic quality of chrysanthemum (Dendranthema grandiflora T.) flowers as affected by the desiccants. $J$. Agrocrop. Sci., 2: 11-14. 
Panse, V.G. and Sukhatme, P.V. 1985. Statistical methods for agricultural workers. Indian Council of Agricultural Research, New Delhi.

Peggy, B. 1978. Preserving flowers with silica gel. Information services, Canada. Department of Agriculture, Ottawa. KIAOC7.

Perinban, S., Majumdar, J., Singh, B., Rai, T. and Kumar, R. 2014. Dried flowers: a new paradigm in Floriculture. http://www.krishisewa.com/cms/articles /pht/394-dried-flowers.html.

Rajesh, B., Moona., Dhiman, S.R. and Thakur, K.S. 2006. Standardization of drying techniques of chrysanthemum (Dendranthema garndiflora Tzvelev.). J. Orn. Hort., 9: 159-163.
Safeena, S.A. and Patil, V.S. 2013. Effect of hot air oven and microwave oven drying on production of quality dry flowers of Dutch roses. J. Agric. Sci., 5: 179-189.

Sangama. 2004. Dehydration and product diversification of helichrysum flowers., J. Orn. Hort., 7: 376-380.

Singh, A., Dhaduk, B.K. and Singh, R.R. 2004. Effect of different temperatures and embedding media on flower dehydration of Zinnia. Ind. J. Hort. Sci., 61: 249-252.

Susan. 1990. Dried flowers. Merchants Ltd., Ferry House, London. 144.

Veugopal, C.K. and Patil, A.A. 2000. A Note on the effect of drying methods and temperatures on colour intensity of everlasting flower. Karnataka J. Agric. Sci., 13: 793-794.

\section{How to cite this article:}

Sindhuja, S., T. Padmalatha, A.S. Padmavathamma and Prasad, A.L.N. 2017. Studies on Different Methods of Drying in Carnation. Int.J.Curr.Microbiol.App.Sci. 6(8): 870-882. doi: https://doi.org/10.20546/ijcmas.2017.608.110 